\title{
Ampulla of Vater Cancer TNM Finding v8
}

National Cancer Institute

\section{Source}

National Cancer Institute. Ampulla of Vater Cancer TNM Finding v8. NCI Thesaurus. Code C134836.

A finding about one or more characteristics of ampulla of Vater cancer, following the rules of the TNM AJCC V8 classification system. This staging system and classification does not apply to well-differentiated neuroendocrine (carcinoid) tumors but does apply to high-grade neuroendocrine carcinomas, such as small cell carcinoma and large cell neuroendocrine carcinoma. (from AJCC 8th Ed.) 